\title{
Law and the practice of politics in the Canadian Department of Justice: completing confederation
}

\author{
DR JONATHAN SWAINGer \\ Professor of History, Department of History, \\ University of Northern British Columbia
}

n the broadest possible sense, the law occupied a central role in transforming the mid-
nineteenth-century British North American colonies into the Canadian Confederation of
1867. ${ }^{1}$ With more than a passing nod to Enlightenment notions of the centrality of rights
and the desirability of founding nations on written constitutions, beginning with the
Charlottetown Conference of 1864 , constitutional negotiation and authorship mapped the
path to the union of Upper and Lower Canada with New Brunswick and Nova Scotia. ${ }^{2}$
Given the profession's prominence in colonial life and politics, its role in the process was
hardly surprising. Of the 30 men who participated at some stage of these discussions, 20
were associated with legal practice. The extent to which the law played an important role in
fostering a sense of the new nation and its ideals - an effort revealed in the standardisation
of a number of legal institutions and practices, the creation of a national penitentiary
system, the reformation and eventual codification of criminal law, and creation of a
Dominion Supreme Court - is equally intriguing. ${ }^{3}$ Yet, at the same time, the trajectory of
constitutional law took Canada in a direction quite contrary to that intended by Sir John A
Macdonald, a central figure in the Confederation scheme, as well as the nation's first Prime
Minister, Minister of Justice and Attorney General. ${ }^{4}$ The result was double-edged. In one
guise, legal institutions and the law helped set out markers of the new nation's identity,

1 Aspects of this discussion were first broached in Jonathan Swainger, The Canadian Department of Justice and the Completion of Confederation, 1867-1878 (UBC Press 2000).

2 The best treatment of the path to the Canadian Confederation agreement is Ged Martin, Britain and the Origins of Canadian Confederation, 1837-67 (UBC Press 1995). Also see Christopher Moore, 1867: How the Fathers Made a Deal (McClelland \& Stewart Inc 1997) and Ged Martin (ed), The Causes of Canadian Confederation (Acadiensis Press 1990).

3 Histories of the Canadian Supreme Court are James G Snell and Frederick Vaughan, The Supreme Court of Canada: History of the Institution (The Osgoode Society for Canadian Legal History 1985) and Ian Bushnell, The Captive Court: A Study of the Supreme Court of Canada (McGill-Queen's University Press 1992). The Canadian codification of the criminal law was a notable achievement unmatched by the mother country. See Desmond Brown, The Genesis of the Canadian Criminal Code of 1892 (The Osgoode Society for Canadian Legal History 1989) and his masterful edited collection of documents on the process published as The Birth of a Criminal Code: The Evolution of Canada's Justice System (University of Toronto Press 1995).

4 Martin argues that Macdonald's emergence as a political leader was partly attributable to his legal skills that 'made him a master of official business'. Macdonald reportedly drafted 50 of the 72 Quebec resolutions in 1864. See Ged Martin, Canadian History: A Play in Two Acts - Inaugural Lecture for the University of Edinburgh Centre of Canadian Studies (Centre of Canadian Studies 1999) 10. 
while, at the same time, judicial interpretation unravelled the centrist constitutional identity that Macdonald and like-minded individuals envisaged for Canada.

Considered from the vantage point of the present, these developments underscore questions about law, its interpretation and its application within the political machinery of the new Dominion. In particular, a telling illustration is the degree that these notions played a pivotal role in the change that overcame Sir John A Macdonald in the mid-1870s. Schooled in Upper Canada's patron, client and brokerage environment, Macdonald's conduct of both private and public affairs demonstrated sharp political skills, scepticism concerning the reformability of human beings, and modest expectations about the law as a device to independently initiate and sustain change. ${ }^{5}$ Although his disarming bonhomie in marshalling public men and political support remained largely intact, he became increasingly inflexible and prone to constitutional battles after returning from the political wilderness in the run-up to the national election of 1878.6 For someone whose public life often hinged on knowing when and where to choose his legal and political contests, Macdonald's instincts seemingly abandoned him, especially in those constitutional struggles of the early and mid1880s. In broadening our gaze to consider the Department of Justice we find evidence of an increasingly literalist interpretation of law and legal remedy between 1867 and 1878, suggesting that Macdonald's altered behaviour possibly owed something to the shifting mentalities of government as the collection of colonies articulated a regime of practices to mirror a new national existence. ${ }^{7}$ The degree to which Macdonald acquiesced in these new practices or was simply wrong-footed is unclear but his increasingly belligerent outlook signalled a deviation from the methods upon which he had built his career and ultimately fed into a series of constitutional confrontations undermining his own vision of the Canadian Confederation.

Centred on the 11 years after the union of 1867 hardened into shape, this article examines the evolution of the Attorney General's functions in mid-nineteenth century British North America leading to the creation of a Dominion Department of Justice and its role in law and statecraft in the early Confederation era. Brought into existence during Sir John A Macdonald's first term as Prime Minister, the department and its approach to managing the government's legal affairs initially mirrored its architect's method in all things legal and political. Macdonald's political roots adhered to the notion that the law's strength was to be found in creating a superstructure within which private citizens might better direct their own affairs and those with others, where society is protected from those who failed to follow rules for the common good, where governments make informed decisions about the allocation of resources, and where men of public affairs accessed the means to seek out accommodations to ensure effective governance. His was a 'governmentality' emphasising tactics rather than law and that used the law and its interpretation as tactics in a broader

5 Mitchell Dean's notion of conduct informs this discussion; see Dean in Governmentality: Government and Rule in Modern Society (2nd edn, Sage 2010) 17. On the political culture that produced Macdonald and his generation, see S J R Noel, Patrons, Clients, Brokers: Ontario Society and Politics, 1791-1896 (University of Toronto Press 1990). Additional impressions are found in David Mills, The Idea of Loyalty in Upper Canada, 1784-1850 (McGillQueen's University Press 1988).

6 For Macdonald's political ideas and style as well as his tumultuous career viewed through his Kingston connections, see Ged Martin's splendid study, Favourite Son? John A Macdonald and the Voters of Kingston, 1841-1891 (Kingston Historical Society 2010). On the largely accidental unveiling of political picnics as a part of electioneering, see the most recent full biographical treatment of Macdonald by Richard Gwyn, Nation Maker: Sir John A Macdonald: His Life and Times (Vintage Canada 2011) 284-85.

7 Dean explores Michel Foucault's language around governmentality and regimes of practices in Dean (n 5) 24-28. See, more generally, Michel Foucault, 'Governmentality' in Graham Bruchell, Colin Gordon and Peter Miller (eds), The Foucault Effect: Studies in Governmentality (University of Chicago Press 1991) 87-104; and Colin Gordon, 'Government Rationality: An Introduction' in the same essay collection, 2-3. 
enterprise that, for Macdonald, was the statecraft of building a new nation. ${ }^{8}$ A combination of ministerial inexperience and the increasing presence of legally trained individuals in the Department of Justice abandoned this approach after 1873 in favour of a more rigid and prescriptive approach to legal problem-solving. The advantage gained in playing the long game wherein decisions not to act or do so indirectly were an integral element in the older regimes of practices was shelved in favour of a new strategic logic favouring an activist Dominion approach to legal problem-solving.

What follows is a two-part exploration of the congruence of law and politics revealed in the statecraft practised by the Canadian Department of Justice during the completion of Confederation from 1867 to 1878 . Section one examines the historic law officers in British North America and draws particular attention to their assumption of an overtly political character, a process culminating in the creation of a Dominion Department of Justice led by a Minister of Justice who also acted as the Attorney General. The political environment in the colonial world placed increasing pressure of effective public leadership in the aftermath of the establishment of responsible government, and those possessed of legal training and the skills of marshalling men were at a premium in an environment where political parties were 'but loosely organized'. ${ }^{10}$ It was in this setting that the Attorney General emerged as a pivotal figure and consequently the question of the extent to which political leadership compromised the legal counsel expected of the law officer attracted increasing attention. Although given voice during the two decades before 1867, concern over the politicisation of the Attorney General's office was invariably hobbled by ideological assumptions about the law and thus, within a year of Confederation, the Dominion government of Sir John A Macdonald unveiled the new Department of Justice that housed both a Minister of Justice and Attorney General. The means whereby the department performed its advisory functions and the changing tenor of that advice forms the second part of this discussion. Infused with the flavour of Macdonald's political methods, the department initially conceived of the law as a tactic employed in a broader political setting but, after the Liberal electoral victory of 1873 , the literal application of legal remedy as an end in itself emerged as a preferred course of action. A consequence of ministerial inexperience, the concomitant reliance on the rising number of legally trained staff in the department created an increasingly legalistic approach to governance. Consequently, by the time that Sir John A Macdonald successfully returned to office in 1878, the department's advisors had grown increasingly bold and arguably overconfident in their ability to wield the law for the Dominion's cause.

\section{The politicised Attorney General}

A basic paradigm that informed how most professionals and much of the public regard the law framed the ideological mindset for the law's contribution to the completion of confederation. Canadian legal scholar Harry W Arthurs has described the outlook in this sense:

The law is formal; it exists as a thing apart from society, politics, or economics; law has the capacity to achieve, and does achieve, results by encouraging or discouraging behaviour, by attaching specified consequences to behaviour that

8 Foucault (n 7) 95.

9 Simon Gunn notes that early arguments about hegemonic power acknowledged the authority inherent in the ability not to act and not to decide. See Gunn, 'From Hegemony to Governmentality: Changing Perceptions of Power in Social History' (2006) 39(3) Journal of Social History 706.

10 J M S Careless, 'The Place, the Office, the Times, and the Men' in J M S Careless (ed), The Pre-Confederation Premiers: Ontario Government Leaders, 1841-1867 (University of Toronto Press 1980) 6. 
facilitate it, deter it or undo its harmful effects; law is made and administered by the state; and access to law is provided in courts by legal professionals - lawyers and judges - who invoke a body of authoritative learning in order to argue and decide cases. ${ }^{11}$

Essentially, the law and its practitioners were 'apolitical and necessary'. 12 Common law training reinforced this ideology through the assertion that those schooled in the law marshalled highly specialised and ancient knowledge affirming the status of those possessed of that learning. Fashioning the link, American legal historian Robert Gordon argued:

The tradition associated law with both science and high culture, and justified the prestige and power of its practitioners. Law was authoritative because it was autonomous and its autonomy derived from two sources, its formality (or technicality) and its antiquity. ${ }^{13}$

Most practitioners would have disavowed such lofty intellectual pretensions and sought refuge in the self-acclaimed role as skilled artisan applying technical rules. This merely substituted one characterisation for another; lawyers were apolitical because they applied ancient principles that were uncoloured by contemporary political interests or they were apolitical because they pulled levers in a mechanical legal structure.

While the office of Attorney General has interwoven law and politics since its origins, the open acknowledgment of this marriage in the Canadas began in the aftermath of the 1837 and 1838 rebellions when the task of examining the circumstances leading to the outbreak fell to the newly minted Governor General, Lord Durham. The subsequent report highlighted the irresponsible nature of colonial government in that 'The Executive Council, the law officers, and whatever heads of departments are known to the administrative system of the Province, were placed in power, without any regard to the wishes of the people or their representatives. ${ }^{14}$ Durham's notion of responsibility raised two specific issues for the Attorney General. Legislative responsibility meant that when tendering legal advice to the cabinet and assembly, the Attorney General did so as a political animal. Further, the Attorney General's position as head of a department of state meant that the chief law officer was to be accountable for the sound management of that department. The question, of course, was how was this to be defined? Was soundness a matter of bureaucratic efficiency, the wisdom of the legal counsel, or the degree to which that counsel aligned with the government's policy objectives? Sorting out the implications of Durham's reforms fell to Charles Poulett Thomson who, upon his appointment as Governor General of British North America, assumed his peerage as Lord Sydenham. Influenced by Benthamite utilitarianism, Sydenham embraced centralisation and reform in the united Canadas as the key elements in solidifying imperial bonds and preventing further outbreaks of

11 H W Arthurs, 'Without the Law': Administrative Justice and Legal Pluralism in Nineteenth-Century England (University of Toronto Press, 1985), p. 1.

12 David Sugarman, 'Law, Economy and the State in England, 1750-1914: Some Major Issues' in David Sugarman (ed), Legality, Ideology, and the State (Academic Press 1983) 231.

13 Robert Gordon, Introduction: J Willard Hurst and the Common Law Tradition in American Legal Historiography' (1975) 20 Law \& Society Review 31.

14 Gerald Craig (ed), Lord Durbam's Report (McClelland \& Stewart 1963) 55. The emphasis is mine; Durham evidently thought that the Attorney General was, in terms of responsibility, no different than any other public figure. On Lord Durham, see Ged Martin, 'John George Lambton' in Dictionary of National Biography <www.oxforddnb.com/view/article/15947?docPos $=2>$ accessed 2 May 2011. Janet Ajzenstat notes that Durham believed that responsible government would counter democratic tendencies in Upper and Lower Canada. See Janet Ajzenstat, The Political Thought of Lord Durham (McGill-Queen's University Press 1988) $52-53$. 
disaffection. ${ }^{15}$ Indeed, Sydenham and Colonial Secretary Lord John Russell agreed that a complete reorganisation of the local departmental structure had to occur before any fundamental reordering of colonial government. ${ }^{16}$ Not only did this place the Attorney General at the head of his own department, but also the direct responsibility of the other departmental heads encouraged an increased reliance on the Attorney General for guidance in the formulation of a wide range of government initiatives. ${ }^{17}$ It was, within the broader context of empire politics, a singular transformation. Before Durham and Sydenham, colonial Chief Justices were regular attendees in Cabinet and advisers to the executive. ${ }^{18} \mathrm{By}$ the end of the 1840s, the reform of conduct unveiled en route to responsible government confined the judiciary to the bench and the Attorney General controlled the centre of colonial politics and governance. ${ }^{19}$ It was a fundamental transformation not only in how law and governance would intersect in British North America but it signalled the emerging difference between the colonies and England despite continuing rhetoric of shared traditions, ideals and practices. ${ }^{20}$

Responsible government, the parallel emergence of political parties and the ascent of legally trained individuals to positions of political leadership meant that, it became the practice for the leader of the government party to take the office of the Attorney General'. ${ }^{21}$ Once again, the law adviser's position revealed the congruence of law. These events had not created the intersection but rather confirmed that the notion of an apolitical law officer was a fiction. Indeed, as J E Hodgetts writes:

by the time responsible government had been granted, the offices of the Attorney General for Canada East and Canada West had become the centres where parliamentary strategy was planned and major administrative decisions were reached. It was no accident, then, that found the two premiers most frequently operating from these two offices. ${ }^{22}$

Indeed, the expanding political activities of the Attorneys General made it increasingly difficult to perform their traditional legal functions by 1846 since the law officers were providing:

15 See Ian Radford, 'Sydenham and Utilitarian Reform' in Allan Greer and Ian Radford (eds), Colonial Leviathan: State Formation in Mid-Nineteenth Century Canada (University of Toronto Press 1992) 81. On Lord Sydenham, see Phillip Buckner, 'Charles Poulett Thomson' in Dictionary of National Biography <www.oxforddnb.com/view/article/27294?docPos=3> accessed 2 May 2011.

16 J E Hodgetts, Pioneer Public Service : An Administrative History of the United Canadas, 1841-1867 (University of Toronto Press 1955) 26. Also see, Donald Creighton, John A Macdonald: The Young Politician (Macmillan Company of Canada Ltd, 1952) 70-71.

17 Hodgetts (n 16) 27, and T D McGee, 'Report of T D McGee on the Public Departments', 1863, National Archive of Canada (NAC), Record Group (RG) 1, E7, vol. 59A, 32-33. See Robin B Burns, 'Thomas D'Arcy McGee', Dictionary of Canadian Biography, vol IX (University of Toronto Press 1976) 489-94. See David A Wilson's biography of D'Arcy McGee, Thomas D'Arcy McGee: Passion, Reason, and Politics, 1825-1857 (McGillQueen's University Press 2008) and Thomas D'Arcy McGee: The Extreme Moderate, 1857-1868 (McGill-Queen's University Press 2011).

18 See Paul Romney, Mr Attorney: The Attorney General for Ontario in Court, Cabinet, and Legislature, 1791-1899 (The Osgoode Society for Canadian Legal History 1988) and Patrick Brode, Sir John Beverley Robinson: Bone and Sinew and the Compact (The Osgoode Society for Canadian Legal History 1984).

19 The phrase 'reform of conduct' is taken from Dean (n 5) 32. It must be noted that prior to developments in the united province of Canada, responsible government in British North America was established in Nova Scotia on 2 February 1848.

20 Phillipa Levine admits that despite being 'a significant arena' for political experimentation as the empire matured in the nineteenth century, Canada has been 'neglected in histories of the British Empire'. See Levine, The British Empire Sunrise to Sunset (Pearson Longman 2007) 42.

21 Romney, (n 18) 159-60.

22 Hodgetts (n 16) 272-73. The emphasis is mine. 
much of the central co-ordination which was expected of cabinet as a body. Not only were they responsible for directing political strategy in Parliament but also their legal abilities induced other departments to appeal to them for rulings - not always on points of law - which in turn came to be treated as rulings of the whole cabinet. ${ }^{23}$

Inasmuch as the development signalled both the prominence of the law officers and the political timidity of their colleagues, it was also rather ironic. While on the one hand it remained necessary to maintain the fiction of law's apolitical character, it had also become convenient for legislators to assert the legal character of every decision they faced rather than shoulder the political responsibility for running their respective departments. It was, of course, this exact behaviour compelling D'Arcy McGee to conclude in 1863 that the law officers were assuming too much political responsibility for the other departments. ${ }^{24}$

Documenting the Attorney General's evolution over the previous 20 years, McGee's report fell short of being prescriptive. For example, the innovation of registering the various opinions delivered by the two Attorneys General was a positive practice. Unfortunately, it was a policy followed unevenly. While the directive recognised the utility of recording and maintaining the government's legal memory, inefficacious practice failed to prevent departing officeholders from carting off opinions and documents. In the end, however, McGee was no more able than earlier commentators and critics to move beyond the fictional separation of law and politics:

it seems by no means necessary that references should be constantly made to the Attorney General East or West, on questions of administration as distinguishable from questions of law. That either of the chief law officers may happen to be Premier and, therefore to be consulted on grounds of public policy, cannot of itself relieve the head of any department from his own proper official responsibility. ${ }^{25}$

On the eve of confederation, therefore, the ideology of law in tandem with the consequences of the Sydenham experiment in responsibility and centralisation moved the Attorney General to the forefront of Canadian politics. While some commentators voiced concern over the Attorney General's rising stature, in part, because it paralleled his withdrawal from the courts, critics merely circled around the deeper issue, failing to recognise the futility of criticising the Attorney General for being political. The widespread subscription to the paradigm of law as apolitical and necessary forestalled such an enquiry and ensured that the apolitical Attorney General would continue to be a paradox during the completion of confederation between 1867 and 1878 .

\section{The art of statecraft}

Introduced during the first week of May 1868 and receiving royal assent three weeks later, the Bill establishing the Department of Justice retained the historic peculiarities of the Attorney General's office under new nomenclature. ${ }^{26}$ The Act brought into existence a department of the civil service called the Department of Justice and created the post of

23 Ibid 83 and Canada, 'Report of a Committee of the Honourable the Executive Council', 12 November 1846, NAC, RG 1, E8, vol 16, 21-23. For ongoing debates concerning the law officers, see appendix to the Ninth Volume of the Journals of the Legislative Assembly of the Province of Canada, 1850, appendix BB.

24 McGee (n 17) 32-34.

25 Ibid 32.

26 Canada, 'An Act respecting the Department of Justice', 31 Victoria, chapter 39. The Bill received second reading on 6 May 1868 and third reading on the following day when it went into Committee of the Whole. See Canada, Debates of the House of Commons (1868) 643 and 646. 
Minister of Justice, who would manage and direct that department and ensure that the administration of public affairs was in accordance with the law and the constitutional division of powers. ${ }^{27}$ As distinct from the minister, the Dominion Attorney General was possessed of all the duties ascribed to the same office in England and enjoyed the powers and duties of the several provincial Attorneys General in the provinces prior to confederation, as long as they did not conflict with the British North America (BNA) Act 1867. This meant that the Dominion Attorney General would not supervise the daily administration of criminal law, but would continue to advise the government: a duty he shared with himself, acting as the Minister of Justice. That a single individual would occupy both roles was a sleight of hand that escaped any discussion in the House of Commons but, as John Edwards has written:

it is difficult, however, if not wholly unrealistic, to make such a distinction drawn by the Act of 1868 in circumscribing the advisory role of the Attorney General, qua Attorney General, to that of advising the Heads of Department, as opposed to the Government itself. ${ }^{28}$

This unrealistic distinction was nonetheless maintained throughout the Act dividing duties between the Minister of Justice and the Attorney General.

The legislation that attracted little comment in Canada nonetheless drew the attention of the Colonial Office. Still, it was the provision allowing the Dominion Attorney General to oversee the criminal law that worried those at 14 Downing Street and not the peculiarity of a single individual occupying two offices that warranted comment. ${ }^{29}$ The concern was quickly dismissed. ${ }^{30}$ Oddly, the casting of the political Minister of Justice with the constitutional review of all provincial legislation, did not give additional reason to pause. For, to the extent that the contrived distinction between Minister of Justice and Attorney General could be maintained at all, the 'apolitical' Attorney General would have been better suited to render these highly sensitive and often contentious judgments. Here, we recall that Sir John A Macdonald was directing events for, if the completion of confederation was to be accomplished by building political understandings within the broad contours of the constitution, it was crucial that the minister, as opposed to the Attorney General, be in place to round off the edges of strict legalistic interpretation. Simply put, the law could not trump politics and, as if to underline this state of affairs, a fortnight after the Department of Justice Act became law, Macdonald issued a memorandum outlining the terms whereby the Minister of Justice would reserve or disallow provincial legislation. ${ }^{31}$

Issued on 8 June 1868, the memorandum on reservation and disallowance clarified that the authority to reserve or disallow was to be used to forward Macdonald's centralist vision of confederation, that the duty of reviewing provincial legislation placed the Minister of Justice in a quasi-judicial role, and that Macdonald remained open to discussions specifying the practical, as distinct from the literal meaning of the constitution. ${ }^{32}$ The blurring of law

27 'An Act respecting the Department of Justice' (n 26) ss 1 and 2.

28 John Ll J Edwards, Ministerial Responsibility for National Security to the Office of Prime Minister, Attorney General and Solicitor General of Canada (The Queen's Printer 1980) 8.

29 On the Colonial Office, see David M L Farr, The Colonial Office and Canada, 1867-1887 (University of Toronto Press 1955).

30 See Department of Justice Mail Registers, 1868, NAC, RG 13, A1, vol 435, no 924 and Colonial Office 42/672, NAC, reel B489, no 11668, 531-36.

31 Robert C Vipond, Liberty and Community: Canadian Federalism and the Failure of the Constitution (State University of New York Press 1991) and Garth Stevenson, Ex Uno Plures: Federal-Provincial Relations in Canada, 1867-1896 (McGill/Queen's University Press 1993) detail the context for the power of disallowance.

32 The following is from the memorandum concerning the powers of disallowance, 8 June 1868, NAC, RG 13, vol 419. Also see Department of Justice letter book, 8 June 1868, RG 13, A3, vol 554, 696-99. 
and politics in such an arrangement was plainly evident and for some it was a contentious mix. From the perspective of young reform politician David Mills, it was simply indefensible that a Minister of Justice could first claim that a provincial enactment was unconstitutional and then adjudicate the matter. According to Mills, declaring a piece of legislation ultra vires was 'a judicial determination and should be left to the courts exclusively'. 33 Indeed, he thought that a provincial court of error and appeal should constitute itself 'a Judicial Committee of the Privy Council' and then, with the provincial Attorney General arguing in favour and the Dominion Attorney General arguing against, a judge would adjudicate the matter prior to the Governor General actually disallowing any local legislation. ${ }^{34}$ The difference between the two outlooks is instructive. Appalled that 'Macdonald behaved as if the highest act of federal statesmanship was to assess the national interest case by case and act accordingly', Mills felt that 'federal statesmanship consisted, rather, in understanding and respecting the division of authority set down in the constitution, the fundamental law'. 35 Obviously, such a literal approach held little appeal for a Dominion Minister of Justice whose duty was to identify the interests of the whole Dominion' while seeking out a balance between the letter and spirit of the law against broader political, economic and social interests. According to some, in adopting this course of action, Macdonald was actively attempting to resolve the tension between the exclusive areas enumerated for provincial jurisdiction and the Dominion's general authority as outlined in the BNA Act. ${ }^{36}$ His were the goals of a politician seeking political order and not a lawyer seeking legalistic certainty.

A circular confirming the Attorney General's pivotal role as the Dominion government's legal persona on 11 June 1868 followed the creation of the Department of Justice and the memorandum on disallowance and reservation. Consistent with the centralising flavour of the early Sydenham reforms and the Department of Justice Act, the circular specified that the Attorney General, as distinct from the minister, was charged with advising all departmental heads upon matters of law and was 'entrusted with the regulation and conduct of all litigation for or against the Crown and any public department in respect of any subjects within the authority and jurisdiction of the Dominion'. ${ }^{37}$ Revealing a persistent lack of co-ordination in managing legal business, the memorandum requested that the various departments of state provide a summary 'of all suits or matters in litigation' as well as the 'names and residences of the professional Gentlemen in whose conduct they may have been placed, to enable me to see that the same are in proper train'. Macdonald also requested the forwarding to the ministry of all documents involving litigation 'to enable me to take such proceedings as may be deemed advisable'. ${ }^{38}$ Coming as it did, less than a year after the proclamation of the new Confederation and within a month of creating the Department of Justice, the move to coordinate legal counsel in the person of the Attorney General represented the final stage in clarifying the Dominion government's legal identity. Inasmuch as the Dominion government had put its legal house in order, the practical implications of these efforts remained unclear, as did their impress on the management of

33 Daily Journal (4 May 1868), David Mills Papers, box 4285, file no 244, University of Western Ontario Regional Room, London, Ontario. The entry over a month before the memorandum's release indicates that Macdonald circulated a draft among prominent lawyers for commentary before finalisation. Mills noted that Macdonald had initially proposed two grounds for disallowance: an act being contrary to public policy and its being ultra vires.

34 Daily Journal (4 May 1868).

35 Vipond ( n 31) 156.

36 Ibid 116.

37 Department of Justice Circular, 11 June 1868, NAC, RG 13, accession 86-87/361, box 2, file 13/1868.

38 Ibid. 
the government's affairs. For while Macdonald invariably preferred that the large questions of governance and public policy would be shielded from the vicissitudes of law, the realities of the new nation challenged such aspirations, leaving the department with a more modest goal of attempting to ensure that nothing untoward occurred within areas of Dominion jurisdiction. The department's composition offers clues that the pursuit of this task was not to be a legalistic contest.

The character and qualifications of those charged with the duty of protecting the Dominion government's legal interests underwent important changes during the completion of confederation between 1867 and 1878. While it was true that in the early years of confederation the Dominion departments of state 'were small enough to enable energetic ministerial heads to attend personally to much of the day-to-day business', the press of events in the Department of Justice placed an enormous responsibility upon the deputy minister. ${ }^{39}$ In this, a staff filled almost exclusively by English-speaking clerks, most of whom had worked for the Attorney General's office in Upper Canada, supported the deputy. Although one might expect familiarity with the law to have been a pre-condition for departmental work, beyond the deputy minister this was not initially the case. In fact, the eventual arrival of additional legally trained individuals reveals that the influence of legal education in the department's operation was a complex matter. Passing the Bar ensured neither the ability nor the will to become a knowledgeable practitioner or legal advisor and further, if a young lawyer was especially skilled, it seems unlikely that a career in the bureaucracy would be particularly attractive. ${ }^{40}$ In truth, other than Hugh Richardson and Zebulon Lash, there were few examples of individuals who enjoyed notable success after leaving the bureaucracy. ${ }^{41}$ While a keen legal mind could succeed in the department, the politically pragmatic approach to problem-solving offered limited appeal for expansive legal minds and especially those inclined to the instrumental application of the law. During these years, the result was a department staffed by competent if unspectacular individuals.

The deputy minister was unquestionably the most important figure in the department's daily operation. Responsible for the finalisation of all opinions, memorandums, edicts, orders and directives, the deputy was the conduit between the minister and the Department as well as between the Department and the Dominion and provincial bureaucracies. During the completion of confederation, the department was especially fortunate to have two adept deputies: Hewitt Bernard and Zebulon Lash. Having arrived in Upper Canada from Jamaica in 1851, Bernard had intended to establish a law practice. Hired as Macdonald's secretary on 15 February 1858, chief clerk since 4 March 1859, and less dutifully as his brother-inlaw since 16 February 1867, Bernard was named Deputy Minister of Justice by an Order in Council on 29 May 1868; one day after the Department of Justice officially came into

39 J E Hodgetts, The Canadian Public Service: A Physiology of Government, 1867-1970 (University of Toronto Press 1973) 49.

40 Cindy Sondik Aron has argued that employment in the bureaucracy often corresponded to aspirations of middle-class stability; see Sondik Aron, Ladies and Gentlemen of the Civil Service: Middle-Class Workers in Victorian America (Oxford University Press 1987).

41 Hugh Richardson's judicial career in western Canada has been subjected to critique in recent years which has called his abilities into question. For the critique, see Bob Beal and Barry Wright, 'Summary and Incompetent Justice: Legal Responses to the 1885 Crisis', in Barry Wright and Susan Binnie (eds), Canadian State Trial, vol III: Political Trials and Security Measures, 1840-1914 (The Osgoode Society for Canadian Legal History 2009) 353-410; J M Bumsted, 'Another Look at the Riel Trial for Treason' in ibid 411-50; and Bill Waiser, 'The White Man Governs: The 1885 Indian Trials', in ibid. 451-82. For a more positive assessment based on a close reading of Richardson's career on the bench, see Shelly A M Gavigan, 'The First Nations and the First Criminal Court in the North-West Territories, 1870-1903' (SJD thesis, University of Toronto 2008) 86-94. Gavigan's dissertation is being prepared for publication as 'Of course no one saw them': Criminal Law on the Aboriginal Plains, 1870 - 1905 (UBC Press and the Osgoode Society for Canadian Legal History forthcoming 2012). 
existence. ${ }^{42}$ The heart of the staff until retiring because of ill health in 1876, Bernard provided constancy, especially during the early years of the Mackenzie government when ministers passed through the department at an alarming rate. Once it became clear that Bernard's tenure as deputy was to end, Liberal Minister of Justice Edward Blake offered the position to Zebulon Lash, then a 30-year-old lawyer practising in Toronto where he lectured in commercial and criminal law for the Law Society of Ontario. ${ }^{43}$ Blake had described the work as 'arduous but very pleasant and after attaining familiarity with the general run of the office can be easily managed by a man of energy, system, and powers of organisation'. ${ }^{4}$ Lash admitted that the offer was a surprise and that the opportunity of working with Blake was appealing, but the monetary considerations of giving up private practice necessitated his refusal. ${ }^{45}$ Blake persisted and on 26 April Lash accepted the office he would hold until late May 1882, at which time he left and rejoined his former minister in private practice as a partner in Blake, Lash, Cassels and Holman. ${ }^{46}$

Beyond the deputy minister, there was a surprising absence of legally trained individuals in the department until Hugh Richardson's appointment as chief clerk on 26 October 1872.47 Additional lawyers arrived over the next few years. The first appointment to the department during the Mackenzie administration involved the hiring of 55-year-old lawyer Augustus Keefer as a junior second-class clerk on 1 January 1874; a position he would hold for less than three years owing to poor health. ${ }^{48}$ Citing the 12 October 1872 Order in Council recommending that the department needed a barrister from the province of Québec, Minister Télesphore Fournier acquired George Duval as a private secretary on 28 July $1874 .{ }^{49} \mathrm{He}$ later rose to the position of chief clerk while Richardson filled in for Bernard whose health was collapsing. ${ }^{50}$ Educated at McGill University in Montréal where

42 J K Johnson (ed), The Letters of Sir John A Macdonald, 1836-1857, vol II (The Queen's Printer 1968) 51 and 126-27; Order-in-Council no 534/1868, 29 May 1868, NAC, RG 2. For biographical detail on Bernard, see (1893) 29 Canada Law Journal 130-31, and 149-50; W Stewart Wallace (ed), 'Hewitt Bernard' in The Dictionary of Canadian Biography, vol 1 (The Macmillan Company of Canada 1945) 45; and P B Waite, 'Hewitt Bernard' in Dictionary of Canadian Biography, vol XII (University of Toronto Press 1990) 97-98.

43 George Maclean Rose (ed), 'Zebulon Aiton Lash' in Cyclopaedia of Canadian Biography: Being Chiefly Men of the Time (Rose Publishing Company 1886) 657. Also see Henry James Morgan, The Canadian Men and Women of the Time: A Handbook of Canadian Biography of Living Characters (William Briggs 1912) 638-39; C W Parker, Who's $W$ ho and Why, vols 6 and 7 (International Press 1914) 1361; W Stewart Wallace (ed), Dictionary of Canadian Biography, vol II (Macmillan Company of Canada 1945) 344; and Theodore D Regehr, 'Zebulon Aiton Lash', in Dictionary of Canadian Biography, vol XIV (University of Toronto Press 1998) 97-98.

44 Edward Blake to Z A Lash, private, 18 April 1876, Archives of Ontario (AO), Manuscript Series (MS) 20 (19), 211-12.

45 Lash to Blake, NAC, Manuscript Group (MG) 27 I D2, reel M244, 19 April 1876.

46 Lash to Blake, ibid 26 April 1876. Lash accepted a day later; see Lash to Blake, ibid. 27 April 1876. Order in Council no 1190/1882, 23 May 1881, NAC, RG 2.

47 Order in Council no 984/1872, 26 October 1872, NAC, RG 2. Bernard's memorandum of 8 October 1872 requesting additional help began with the assertion 'that for some time past it has been found impossible, with the present staff of the Department of Justice, to keep up anything approaching to the efficient discharge of the daily business referred to it'. See Hewitt Bernard to the Privy Council, 8 October 1872, in Order in Council no 976/1872, 12 October 1872, NAC, RG 2.

48 Keefer was admitted to the Upper Canadian Bar in 1850. Henry J Morgan (ed), The Canadian Legal Directory: A Guide to the Bench and Bar of the Dominion of Canada (Toronto 1878) 50. Memorandum from Edward Blake, 16 November 1876 in Order in Council no 1077/1876, NAC, RG 2.

49 Order in Council no 977/1874, 28 July 1874, NAC, RG 2. On the civil law tradition within the Canadian Department of Justice, see Mélanie Brunet, Out of the Shadows: The Civil Law Tradition in the Canadian Department of Justice, 1868-2000 <www.justice.gc.ca/eng/dept-min/pub/civil/index.html> accessed 3 June 2011.

50 Order in Council no 1532/1874, 18 December 1874, NAC, RG 2, and memorandum of Télesphore Fournier, 18 December 1874, NAC, RG 13, A4, vol 1382. For the original order, see Order in Council no 976/1872, 12 October 1872, NAC, RG 2 and Hewitt Bernard's memorandum of 8 October 1872 (n 47). 
he acquired valuable knowledge of the French Civil law, the appointment of Augustus Power in July 1875 brought another legal mind into the department. ${ }^{51}$ Finally, weeks after Lash replaced Bernard as Deputy Minister, John L B Fraser, a young barrister from Osgoode Hall, joined the staff in the aftermath of Richardson's departure to become Stipendiary Magistrate in the North West Territories. ${ }^{52}$

Several impressions emerge from a survey of departmental personnel. Supported by a small number of clerks without any legal training, at the outset Deputy Minister of Justice Hewitt Bernard was effectively the Department of Justice. ${ }^{53}$ While he had the benefit of Sir John's legal experience, on a practical basis Bernard was very much on his own until 1872 and Richardson's appointment. Indeed, as Bernard wrote to Senator Alexander Campbell in August of that year:

There is no Minister here, and I find that the Departments generally come to ask me what should be done in matters arising. In addition to which Sir John has evidently put everything coming to him, which is not absolutely electioneering, into my charge: and I have to answer letters and telegrams and look after important business all day, and that from British Columbia to Halifax. ${ }^{54}$

Essentially, the department's (and by extension the Dominion government's) legal imagination was limited to what Bernard and Macdonald were willing to countenance. Even had both been brilliant legal minds, and there is little evidence to sustain such an attribution, the department was over-matched by the volume and variety of legal issues arising from a new and diverse nation. Bernard acknowledged as much in a letter to Judge J R Gowan wherein the soon to be deputy minister admitted that his was an Upper-Canadian perspective on the nation. 55 The implication of this self-awareness was instructive for, until the mid-1870s, the department was almost exclusively composed of individuals from the pre-confederation Attorney General's office in Upper Canada. Theirs were the habits of office rooted in the political deadlock of the late 1850s and early 1860s; it was a culture valuing flexibility rather than hardened legal principles. Macdonald, as the only Minister of Justice and Attorney General from 1868, perpetuated this outlook. This stood in sharp contrast to developments following the victory of Alexander Mackenzie's Liberal government that arrived in 1873 full of righteous indignation, high principles, a shortage of

51 Power, whose father William P Power had sat on the Superior Court of Lower Canada, was appointed to the civil service on 7 December 1874 and transferred to the Department of Justice on 1 July 1875. See The Civil Service List of Canada, 1887 (The Queen's Printer 1888) 2. See 'Augustus Power' in Morgan (n 43 ) 914

52 See 'Hugh Richardson' in Morgan (n 43) 939 and Order in Council no 836/1876, 18 September 1876, NAC, RG 2. Also see Thomas Flanagan, 'Hugh Richardson' in Dictionary of Canadian Biography, vol XIV (N 43) $870-71$.

53 A return of all the names of individuals employed by the Department of Justice on 22 November 1867 indicates that including the Attorney General, there were eight men on staff. See 'Return of the names of all of the officials and employees now concerned with the office of the Minister of Justice', 22 November 1867, NAC, RG 13, vol 16, file 310. Also see The Blue Book; or, Statement of the Public Service of the Former province of Canada for the Half-Year Ended 30 th June 1867 (Ottawa, 1868). The contingent would rise to 11 and then fall back to nine over the ensuing decade. See Zebulon Lash, 'Pay list and establishment of the Department of Justice, 1878, NAC, RG 13, vol 419.

54 Hewitt Bernard to Alexander Campbell, 23 August 1872, AO, Manuscript Unit 469.

55 Hewitt Bernard to James Robert Gowan, 15 August 1867, James Robert Gowan Papers, NAC, MG 27 I E 31. See Desmond H Brown, 'Sir James Robert Gowan' in Dictionary of Canadian Biography, vol XIII (University of Toronto Press 1994) 391-95. 
experience in government and an understandable inclination to enjoy the spoils of office. ${ }^{56}$ Reliant on a bureaucracy of doubtful allegiance, the first three Liberal Ministers of Justice - Antoine Aimé Dorion, Télesphore Fournier and Edward Blake - introduced greater geographical variety and professional training in departmental personnel, the latter of which fostered an increasingly rigid and supposedly more principled approach to its mandate and the rule of law. ${ }^{57}$

Although the consequences of this shift for the returning Macdonald government after 1878 are certain, there was no tipping point when one could draw a line under past practice and herald the new approach to legal counsel. Here we are reminded of John Cell's description of the mid-nineteenth-century Colonial Office where thinking was in a constant state of flux:

At any given moment there is not so much policy as policy formation, an unsettled and changing set of responses by government to the continual interaction among men, forces, ideas and institutions. ${ }^{58}$

Thus, 'thousands of tiny contingent practices' of departmental routine documented both the persistence of older pragmatic approaches and their eventual retreat with the ascendency of new men and ideas. ${ }^{59}$ It was a routine established through what the Civil Service Commission of 1868 described as the department's 'main business' the provision:

of legal opinions given upon references from the other Departments, which are estimated at about 1200 annually, besides numerous verbal references upon questions of law. It has also to examine the legislation of the Provinces, and the bills brought in by private members, and to draft or devise Government bills. ${ }^{60}$

This 'main business' (which was underestimated by 25 per cent in 1868) transpired in concert with the administration of the nation's penitentiaries and prison population, managing both the royal prerogative and applications for remission of sentences, appointing and overseeing members to the senior courts and, by the mid-1870s, bringing the Dominion Supreme Court into existence. ${ }^{61}$ One measurement of the ever-increasing workload was the department registers that recorded every written reference or query received. As reported by successive Liberal Ministers of Justice Edward Blake and Rodolphe Laflamme, department business tripled between 1869 and 1877, rising from 1693 enquiries in the first year with the expectation that in the latter year approximately 5600 would be handled. 62

56 Alexander Mackenzie's government assumed power in the aftermath of the so-called Pacific Scandal in which the Macdonald government was undone by accusations of bribery, dubious contracts for the Canadian Pacific Railway, and disreputable electoral practices. In calling on Macdonald to resign, then Governor General, Lord Dufferin based his concerns, in part, on the ideological construction of the law and the assertion that 'as administrator of justice and the official guardian and protector of the Laws, your responsibilities are exceptional'. See Governor General Lord Dufferin to John A Macdonald, 19 October 1873, NAC, MG 26A, vol 79, 30965-78.

57 Biographical treatments of these Ministers of Justice are found in Swainger, 'Governing the Law: The Canadian Department of Justice in the Early Confederation Era' (PhD dissertation, University of Western Ontario 1991) 78-92.

58 John W Cell, British Colonial Administration in the Mid-Nineteenth Century: The Policy-Making Process (Yale University Press 1970) xi.

59 Robert W Gordon, 'Critical Legal Histories' (1984) 36 Stanford Law Review 84-5 and 90, fn 80.

60 'Department of Justice', First Report of the Civil Service Commission, Canada, Sessional Papers (1869) no 19, 15.

61 These additional responsibilities have been examined in Swainger (n 1).

62 Edward Blake, 'The Teeswater Demonstration' in Reform Government in the Dominion. The Pic-Nic Speeches (The Globe Steam Book and Job Press 1878) 135, and Rodolphe Laflamme, 2 April 1878, Canada, House of Commons Debates (1878) 1585. 
Numbers told only part of the story for they fail to capture the varying amounts of labour involved in each reference. A sliding scale between extremes marked by bureaucratic labour handled by clerks and signed off by the deputy minister and those concerns requiring the minister's political and legal acumen plot the profile of departmental work. The distinction could be as vast as the difference between a routine patent application for the appropriately patriotic Hallam's New Dominion Churn and Washer as compared with the three years of aggravation demanding co-ordination with provincial authorities, as well as international diplomacy with Spain, Great Britain and the United States, aimed at preventing the recruitment of volunteers for a Cuban invasion that was to be launched, in part, from Nova Scotia. ${ }^{63}$ Still, regardless of whether the issue was relatively mechanical or required sustained attention to bewildering and minute detail, in the early years of confederation the goal was constant; Dominion authority should prevail and if concerns emerged, actual legal entanglements were avoidable through mutually beneficial accommodations. Thus, when litigation loomed in 1872 because of the laxity which had crept into the administration of the land reserves running parallel to the Rideau Canal bisecting the nation's capital, Deputy Minister of Justice Hewitt Bernard penned a series of unofficial communications seeking a means of escape, the most illuminating being one sent to the new Prime Minister and Minister of Public Work, Alexander Mackenzie, in June 1874. Asked to issue a land patent for a piece of land falling within the canal reserve, and thus violate both the letter and spirit of the law, Bernard balked:

I think it best to represent to you, in the first instance, unofficially, that I think such a grant would be of a rather dangerous character... I have always had some doubts whether the leases of what are known as Canal lots, to private individuals, could be deemed 'purposes of the canal': but there is enough room for some argument that warehouses and stores for commercial purposes may be deemed so to be. And it has always been the custom in those cases, to give leases only as distinguished from absolute transfers, - and those leases, some for definite terms of years and not to be indefinitely renewable.

To grant therefore to private individuals and thereby absolutely to alienate from the Crown and from 'purposes of the Canal' any portion of the land freely given by [Nicholas] Sparks for such 'purposes' only, is I fear a matter which might involve great difficulty ... I suggest therefore for your consideration whether it is not well to abandon such a grant as is contemplated. I do not think that a lease even for term of years would get over the difficulty. And yet I think it would be injudicious publicly to give the reason which guides my views, as the whole question is one which may bear a different interpretation to that which I put on it. ${ }^{64}$

Bernard's language was instructive. Harbouring doubts as to the practice of granting leases, the deputy minister believed that 'there is enough room' in a definition of 'canal purposes' to permit business and industrial encroachments but that unconditional grants to private individuals were another matter altogether. This uncertainty threatened potentially every sale of reserve land made and Bernard counselled discretion and suggested that the

63 On the Canadian difficulties concerning the Cuban invasion and its context within the Ten Year's War, see Swainger (n 1) 51-53. More generally, see Joan Casonovas, Bread Or Bullets: Urban Labor and Spanish Colonialism in Cuba, 1850-1898 (University of Pittsburgh Press 1998) 97-126 and Ada Ferrer, Insurgent Cuba: Race, Nation, and Revolution, 1868-1898 (University of North Carolina Press 1999) 15-70.

64 Hewitt Bernard to Alexander Mackenzie, 12 June 1874, NAC, RG 13, A3, vol 566, 730-33. The statute to which Bernard referred was Canada, 'An Act to explain provisions of the Ordnance Vesting Act and to remove certain difficulties which have occurred in carrying the said provision into effect', Canada, 9 Victoria, chapter 42. His quotation from the statute was somewhat selective wherein Nicholas Sparks had granted the land 'for the purposes of the said Canal, provided no buildings be erected thereon'. The provision concerning canal purposes been interpreted very broadly and buildings had in fact been constructed within the reserve. 
orchestration of lease was certainly preferable to granting an outright patent. Days later a 40 -year lease with a rent of $\$ 1$ per year was authorised; despite genuine reasons to question Bernard's loyalties - given his Conservative leanings and close ties to his brother-in-law, John A Macdonald - the deputy minister's 'legal' opinion had convinced Mackenzie. ${ }^{65}$ For the early Department of Justice, this was the art of statecraft.

In as much as Bernard's efforts on the canal reserves represented the department's initial approach to orchestrating the law, he was also at hand when a dispute over escheats and forfeitures between the province of Ontario and the Dominion government foreshadowed constitutional battles to come. Escheat was the principle whereby the Crown assumed possession of the property of an individual who died intestate without heirs and the legislation in question was an Ontarian Act providing for the seizure of the estate of an individual convicted of treason or another felony. The seizure was justified as an extension of the Lieutenant Governor's prerogative powers. Liberal Minister of Justice Télesphore Fournier struck down the legislation as ultra vires since the Lieutenant Governors, as Dominion appointees, did not possess prerogative powers, and that all matters relating to criminal law were within Dominion jurisdiction. Bernard's authorship of the initial memorandum on the matter has provided a convenient, if unconvincing explanation, for the jurisdictional dispute. ${ }^{66}$ The source of this disingenuous interpretation was Oliver Mowat, then Ontario's Liberal Premier. ${ }^{67}$ Certainly, had Fournier actually subscribed to Mowat's position, surely the Minister of Justice was of stout enough fibre to stand up to his deputy, rather than cave in on an issue of constitutional interpretation? Yet, rather that consider the possibility that fellow Liberal Fournier actually believed that Ontario's legislation was unconstitutional, it was easier to construct a Macdonaldian conspiracy with Sir John directing events through his brother-in-law and accomplice. ${ }^{68}$ That Edward Blake, who replaced Fournier when the latter was elevated to the newly created Dominion Supreme Court, agreed that all forfeitures for treason or criminal convictions did belong to the Dominion government while, at the same time, departing from the position concerning the Lieutenant Governor's prerogative powers, suggests that there had been room in Bernard's initial memorandum for negotiation, had the political will existed. Blake, however, whose mien envisaged a sharp line distinguishing things legal from those political, opted not for an understanding between gentlemen politicians but for turning the matter over to the Canadian Supreme Court for adjudication. ${ }^{69}$

More broadly, emphasising Bernard's role and his connection to Macdonald substitutes personal intrigue for an understanding grounded in how the Department of Justice had functioned since 1868. Given the department's method of dealing with conflicts, Bernard's memorandum had been an opening gambit in the type of negotiation that occurred prior to the mid-1870s. The process went awry when Fournier simply accepted Bernard's position as being sound from a Dominion point of view, rather than bringing the matter to Mowat's unofficial attention and again when Blake did not seize the opportunity of seeking out an accommodation. Believing that Ontario's position on the prerogative powers was correct, Mowat was especially annoyed that Fournier had officially concurred with Bernard before

65 Department of Justice to Department of Public Works, 16 June 1874, in ibid 770.

66 Romney (n 18) 248.

67 Report of Attorney General Oliver Mowat, 22 February 1875 in W E Hodgins (ed), Correspondence, Reports of the Minister of Justice and Orders in Council upon the subject of Dominion and Provincial Legislation, 1867-1895 (The Queen's Printer 1896) 113.

68 Romney (n 18) 249. Margaret Evans, Mowat's biographer, follows Romney's lead on this view; see A Margaret Evans, Sir Oliver Mowat (University of Toronto Press 1992) 149. Also see Stevenson (n 31) 200-01.

69 Romney (n 18) 249. The Ontario matter never reached the Supreme Court because a Québec Court of Queen's Bench decision settled the matter in the provinces' favour. 
discussing the matter. Reflecting on the breakdown, Mowat notably attempted to resurrect the earlier approach to business:

Sir John Macdonald's course was to correspond privately about provincial Acts which he considered to be ultra vires before putting his objections in final shape. Fournier has not adopted this course, so far at least as Ontario is concerned, either in regard to the escheat Bill or to our general legislation. Do not you think Sir John's plan the better one, at all events as long as the two governments are in accord? ${ }^{70}$

Clearly, Macdonaldian schemes had not caused the skirmish or the ensuing constitutional dispute. Rather, the episode owed its origins to the abandonment of unofficial communications wherein law was as a tactic of statecraft and, in that guise, had successfully defused these situations in the past.

One hastens to add that the die need not have been cast. Upon his return in 1878, Macdonald could have resurrected an approach to governance and legal interpretation seeking out understandings in avoidance of exposing the Dominion government to the uncertainties of litigation and constitutional court challenges. Circumstances had changed and inasmuch as completing the nation's institutional structure had provided fertile ground for accommodations with friend and foe alike, one of the emerging issues of the late $1870 \mathrm{~s}$ and early 1880s was that of fine-tuning the constitutional division of powers. Despite his awareness that the courts would not be allies in forwarding his own vision of the constitution, it seems as if Macdonald could not help himself. ${ }^{71}$ And while he would never again be pushed from office, as early as 1878 there were already signs that time was catching up to Macdonald who was 'strangely unlike the self-effacing, repentant, ageing man' forced to resign five years earlier. ${ }^{72} \mathrm{He}$ has become notably more combative, and the electoral victory of 1878 offered an unexpected chance for redemption and yet another opportunity to champion his vision of Canada:

The second chance would be the last chance. It had come late. It could not be, in the nature of things, as favourable a chance as the first. But it would be the last opportunity he would ever get. ${ }^{73}$

This realisation left Macdonald unwilling to brook opposition to either the style or substance of his governance and it was in his battles over the meaning of the constitution with Ontario Premier Oliver Mowat that Macdonald's increasingly pugnacious attitude was especially evident. To the degree that Macdonald had 'always found it a positive pleasure to do battle', there would be precious little pleasure for Macdonald in these engagements with Mowat, who proved to be a solvent for all the attributes and talents which had been central to Macdonald's career. ${ }^{74}$ As Mowat's biographer A Margaret Evans pointed out, Macdonald's 'famous bonhomie, his skill in the management of men, his powers of conciliation, were not evinced where the provincialist premier was concerned'. ${ }^{75}$ And by the time that Macdonald recognised that Mowat was deadly serious and 'would not be intimidated' in forwarding his own vision of the constitution, the course was unalterable.

70 Oliver Mowat to Edward Blake, 23 June 1875, NAC, reel M-242.

71 John T Saywell, The Lawmakers: Judicial Power and the Shaping of Canadian Federalism (The Osgoode Society for Canadian Legal History 2002) 92.

72 Donald Creighton, John A Macdonald: The Old Chieftain (The Macmillan Company of Canada 1955) 237.

73 Ibid 254.

74 Ibid 322.

75 Evans (n 68) 169. 
Sir John committed himself to a battle that successive rulings of the Judicial Committee of the Privy Council indicated he would not win. ${ }^{76}$

In the course of these constitutional battles, the Department of Justice was hardly covered in glory as the legal adviser to the Dominion government. While Macdonald directed the Dominion charge behind the scenes, after 1878, his new Minister of Justice was the 'uninspired but judicious Nova Scotian' James MacDonald who was of indifferent mettle. ${ }^{77}$ Marshalling the federal case in these clashes required considerable talent and James MacDonald was ill-suited, remaining in office until his May 1881 appointment as Nova Scotia's Chief Justice. ${ }^{78}$ Into his place stepped Sir Alexander Campbell, a long-time associate and occasional business partner of Sir John's. ${ }^{79}$ Hardly a newcomer to federal politics, Campbell had sat in the Senate since his appointment by Macdonald on 23 October 1867 from where he supervised the Post Office throughout Macdonald's first term. ${ }^{80}$ Although more likely to hold Sir John's attention than did James MacDonald, Campbell was no more able to compel the Prime Minister to alter his course in refusing to speak with Mowat, with whom Campbell maintained friendly relations since the time both had clerked in Macdonald's law offices. Still, the one bright spot for the federal cause was the presence of the department's deputy minister, Zebulon Lash. Despite recognised political differences with the incoming Conservatives, Lash was willing to stay in the department where his strong centralist sympathies were welcome. ${ }^{81}$ Although an increase in salary promised by outgoing Minister of Justice Laflamme was not forthcoming, Lash nonetheless received both a financial and professional boost by his appointment 'as counsel in cases in which the Government is interested' ${ }^{82}$ Consequently, Lash presented the Dominion case in Mercer v the Attorney General for Ontario before the Canadian Supreme Court and eventually before the Judicial Committee of the Privy Council (JCPC). Although his argument before the Canadian Supreme Court secured a Dominion victory in the winter of 1881, on appeal the JCPC overturned the result in the summer of $1883 .{ }^{83}$ It would be but one in a series of constitutional defeats for the Dominion government and Sir John A Macdonald's vision of confederation. Having already returned to an increasingly prominent and lucrative private practice specialising in commercial law, with little apparent hesitation Lash safely left the business of advising the Dominion government to others.

76 Ibid 324 and 377.

77 Peter B Waite, Canada 1874-1896: Arduous Destiny (McClelland \& Stewart 1971) 96, and Waite, The Man from Halifax: Sir John Thompson, Prime Minster (University of Toronto Press 1985) 102. MacDonald's name also appears as McDonald and Macdonald.

78 On the politicisation of the judiciary in post-confederation Canada, see Jonathan Swainger, 'A Bench in Disarray: The Quebec Judiciary and the Department of Justice, 1867-1878' (1993) 34(1) Les Cahiers de Droit 59-91 and J Swainger, 'Judicial Scandal and the Culture of Patronage in Early Confederation, 1867-1878' in Jim Phillips, R Roy McMurtry and John Saywell (eds), Essays in the History of Canadian Law vol X: A Tribute to Peter Oliver (Osgoode Society for Canadian Legal History and University of Toronto Press 2008) 222-54.

79 Ged Martin's recently completed article length study of Alexander Campbell paints a fascinating portrait of a public figure beset by health and physical difficulties and a marriage made difficult by his wife's institutionalisation. See 'Alexander Campbell (1822-1892): The Travails of a Father of Confederation' (forthcoming 2012) Ontario History. My thanks to Ged for sharing Campbell's extraordinary history that, for reasons of Victorian sensibilities, remained largely hidden from public discourse.

80 Donald Swainson, 'Sir Alexander Campbell', Dictionary of Canadian Biography, vol XII (University of Toronto Press 1990) 150-54.

81 See Regehr (n 43) 605.

82 R Laflamme to Z A Lash, nd, NAC, RG 13, vol 419; and Report of James Macdonald, 18 June 1879, NAC, RG 2, Order in Council no 914/1879. The appointment was confirmed on 25 June 1879.

83 The Attorney General of Ontario and Andrew F Mercer, The House of Lords and Privy Council, vol 8 (1883) 767. Also see Romney (n 18) 252-55. 
Rooted in an outlook combining the ideology of law with a scepticism concerning the ability of law or legal remedy to effect thoroughgoing reform, regimes of practice in the early Dominion Department of Justice mirrored a confluence of law and politics that was a product of Canada's colonial history. Distinct from English ideals that portrayed an apolitical adviser to the Crown and government, the colonial Attorney General assumed political and governmental leadership in local assemblies and by the time of confederation in 1867, the Attorney General was synonymous with legislative and political power. ${ }^{84}$ This accumulated influence was renovated within the jurisdictional framework of the new union; responsibilities were divided between the provincial and national levels of government and in the Dominion government the responsibility for provision of legal counsel was shared between an apolitical Attorney General, a political Minister of Justice, and a bureaucracy to provide necessary administrative support. The ideology of law and its corollary that those trained in the law were apolitical and possessed a cachet of specialised insight or knowledge framed all these developments. It was an ideology rationalising the prominence of legally trained individuals within a variety of governmental and bureaucratic roles while lending weight and legitimacy to their practices and decisions. The result was that law and accommodations grounded in the confluence of law and politics assumed a central role in clarifying the daily working principles of the new union. Such as it was, the emergent governmentality with its regimes of practices had worked well enough until 1873 when, because of governmental inexperience and consequent reliance on a developing literalist legal culture in the Department of Justice, there emerged an increasing acquiescence in legalistic responses as the favoured tactic in defence of the Dominion government's jurisdictional assertions. On the large constitutional questions of the day, this tactic failed while on almost every front in its oversight of the Dominion's daily legal business, the department was successful in forwarding its version of what constituted 'sound pragmatic common sense'. 85 Depending on where one looked, the Dominion's legal advisors were well versed in the art of government or had dramatically fallen short. ${ }^{86}$

Thanks to the efforts of Alexander Campbell and then John Thompson as consecutive Ministers of Justice, by the late 1880s the department righted itself in returning to less confrontational and more successful approaches to the government's legal business. The department soon shared in reflected glory of former deputy minister George Burbidge and his successor Robert Sedgewick who had played pivotal roles in codifying the criminal law in 1892, then an accomplishment still unmatched in England today. ${ }^{87}$ Wielding the law unnecessarily had not garnered success. It was a telling lesson underlining that in the empire's oldest self-governing jurisdiction, truly effective statecraft was that practised at the confluence of law and politics.

84 The enormity of the gap in practice, let alone ideal, between England and Canada in reference to the Attorney General is shown in a comparison of John L J Edwards' study The Law Officers of the Crown: A Study of the Offices of the Attorney-General and Solicitor-General of England with an Account of the Office of the Director of Public Prosecutions of England (Sweet \& Maxwell, 1964) with that which emerged in the Canadas in the aftermath of responsible government.

85 As cited in Gordon (n 59) 112.

86 Dean (n 5) 28.

87 Burbidge departed the department to become the first permanent justice of the Exchequer Court. See Ian Bushnell, The Federal Court of Canada: A History, 1875-1992 (The Osgoode Society for Canadian Legal History 1997) 81-92. Generally, see Brown (n 3) and, more specifically, Desmond Brown, 'George Wheelock Burbidge' in Dictionary of Canadian Biography, vol. XIII (University of Toronto Press 1994) 135-37 and on Sedgewick see Philip Girard, 'Robert Sedgewick' in ibid 931-34. 
